\title{
Prevalence of the Metabolic Syndrome in Latin America and its association with sub-clinical carotid atherosclerosis: the CARMELA cross sectional study
}

\author{
Jorge Escobedo*1,2, Herman Schargrodsky ${ }^{3}$, Beatriz Champagne ${ }^{4}$, \\ Honorio Silva ${ }^{5}$, Carlos P Boissonnet ${ }^{6}$, Raul Vinueza ${ }^{7}$, Marta Torres ${ }^{8}$, \\ Rafael Hernandez ${ }^{9}$ and Elinor Wilson ${ }^{10}$
}

\begin{abstract}
Address: ${ }^{1}$ Medical Research Unit on Clinical Epidemiology, Mexican Social Security Institute, Mexico City, Mexico, ${ }^{2}$ Gabriel Mancera $222 \mathrm{~m}$ Col. Del Valle, 03100 Mexico City, Mexico, ${ }^{3}$ Department of Cardiology, Hospital Italiano de Buenos Aires, Buenos Aires, Argentina, ${ }^{4}$ InterAmerican Heart Foundation, Dallas, Texas, USA, ${ }^{5}$ InterAmerican Foundation for Clinical Research, New York, New York, USA, ${ }^{6}$ Coronary Care Unit, Centro de Educación Médica e Investigaciones Clínicas "Norberto Quirno," Buenos Aires, Argentina, ${ }^{7}$ Clinical Protocol Manager Canada/Latin America/ Africa/Middle East Region Worldwide Development Operations, Pfizer Inc., New York, New York, USA, ${ }^{8}$ Programa Buenos Aires de Control de Calidad Externo-CEMIC, Buenos Aires, Argentina, ${ }^{9}$ Clinical Pharmacology Unit and Hypertension Clinic, School of Medicine, Universidad Centroccidental "Lisandro Alvarado," Decanato de Medicina, Barquisimeto, Venezuela and ${ }^{10}$ Department of Community and Preventive Health, School of Medicine \& Dentistry, University of Rochester, Rochester, New York, USA

Email: Jorge Escobedo* - jorgeep@unam.mx; Herman Schargrodsky - bubyscha@ fibertel.com.ar; Beatriz Champagne - beatriz.champagne@interamericanheart.org; Honorio Silva - honorio.silva@globecpd.org; Carlos P Boissonnet - pboisson@intramed.net.ar; Raul Vinueza - Raul.Vinueza@pfizer.com; Marta Torres - progba@cemic.edu.ar; Rafael Hernandez - rahernandez001@msn.com; Elinor Wilson - elinor_wilson@ahrc-pac.gc.ca

* Corresponding author
\end{abstract}

Published: 26 September 2009

Cardiovascular Diabetology 2009, 8:52 doi:10.1 186/1475-2840-8-52

This article is available from: http://www.cardiab.com/content/8///52

(C) 2009 Escobedo et al; licensee BioMed Central Ltd.

This is an Open Access article distributed under the terms of the Creative Commons Attribution License (http://creativecommons.org/licenses/by/2.0), which permits unrestricted use, distribution, and reproduction in any medium, provided the original work is properly cited.
Received: 3 August 2009

Accepted: 26 September 2009

\begin{abstract}
Background: Metabolic syndrome increases cardiovascular risk. Limited information on its prevalence in Latin America is available. The Cardiovascular Risk Factor Multiple Evaluation in Latin America (CARMELA) study included assessment of metabolic syndrome in 7 urban Latin American populations.
\end{abstract}

Methods: CARMELA was a cross-sectional, population-based, observational study conducted in Barquisimeto, Venezuela; Bogota, Colombia; Buenos Aires, Argentina; Lima, Peru; Mexico City, Mexico; Quito, Ecuador; and Santiago, Chile. The prevalence of metabolic syndrome, defined according to the National Cholesterol Education Program Adult Treatment Panel III (NCEP ATP III), and associated carotid atherosclerosis were investigated in II,502 participants aged 25 to 64 years.

Results: Across CARMELA cities, metabolic syndrome was most prevalent in Mexico City (27\%) and Barquisimeto (26\%), followed by Santiago (21\%), Bogota $(20 \%)$, Lima (18\%), Buenos Aires (17\%), and Quito (14\%). In nondiabetic participants, prevalence was slightly lower but followed a comparable ranking. Overall, $59 \%, 59 \%$, and $73 \%$ of women with high triglycerides, hypertension, or glucose abnormalities, respectively, and $64 \%, 48 \%$ and $71 \%$ of men with abdominal obesity, hypertension, or glucose abnormalities, respectively, had the full metabolic syndrome. Prevalence of metabolic syndrome increased with age, markedly so in women. Mean common carotid artery intima-media thickness (CCAIMT) and prevalence of carotid plaque increased steeply with 
increasing numbers of metabolic syndrome components; mean CCAIMT was higher and plaque more prevalent in participants with metabolic syndrome than without.

Conclusion: The prevalence of metabolic syndrome and its components by NCEP ATP III criteria was substantial across cities, ranging from I4\% to 27\%. CARMELA findings, including evidence of the association of metabolic syndrome and carotid atherosclerosis, should inform appropriate clinical and public health interventions.

\section{Background}

The concept of the metabolic syndrome has developed in stages over the past 80 years; it is now recognized that the combination of abdominal obesity, glucose metabolism abnormalities, hypertension, and dyslipidemia, accompanied by prothrombotic and proinflammatory states, leads to type 2 diabetes and vascular diseases, including coronary heart disease and stroke $[1,2]$.

Metabolic syndrome predicts total, cardiovascular, and coronary heart disease mortality; in fact, the presence of even 1 or 2 components of the metabolic syndrome increases overall mortality compared with the absence of any component of the metabolic syndrome [3-6]. A 65\% excess risk has been estimated for cardiovascular disease in individuals with the metabolic syndrome [7]. Metabolic syndrome even predicts the occurrence of sudden death, independent of the presence of other cardiovascular risk factors [8]. Metabolic syndrome also predicts the incidence and progression of carotid atherosclerosis [9].

As reviewed recently, worldwide prevalence of metabolic syndrome ranges from $<10 \%$ to as much as $84 \%$, depending on age, region, urban or rural environment, ethnicity, and the definition of metabolic syndrome used [10-12]. In the United States, between 1994 and 2000, prevalence of metabolic syndrome in adults increased from $23 \%$ to $27 \%$ along with an increase in obesity and physical inactivity [13]. Developing regions like Latin America, undergoing sea change in the lifestyle factors contributing to the metabolic syndrome, may see even greater increases in prevalence over a relatively short span of time. Local public health and clinical efforts to stem morbidity and mortality from the metabolic syndrome must be based on the relevant local prevalence of its components. The Cardiovascular Risk Factor Multiple Evaluation in Latin America (CARMELA) study investigated risk factors for cardiovascular disease in 7 Latin American cities, as reported elsewhere [14]. With cardiovascular risk and clinical interventions in mind, the National Cholesterol Education Program Adult Treatment Panel III (NCEP ATP III) criteria [2] were used to assess metabolic syndrome prevalence in CARMELA cities. The association of metabolic syndrome with mean common carotid artery intimamedia thickness (CCAIMT), as a marker of carotid atherosclerosis, was also investigated.

\section{Methods Study Design}

CARMELA was a multistage, cross-sectional epidemiologic study conducted between September 2003 and August 2005, in Barquisimeto, Venezuela; Bogota, Colombia; Buenos Aires, Argentina; Lima, Peru; Mexico City, Mexico; Quito, Ecuador; and Santiago, Chile. The study was conducted according to the Declaration of Helsinki and the Guides for Good Clinical Practice. Approximately 1,600 participants per city between the ages of 25 and 64 years were included, stratified by sex and age (10year groups). The study was approved by an institutional review committee in all participating cities, and all subjects gave informed consent. Study methods are described in detail elsewhere [14].

\section{Anthropometry}

Waist circumference was measured at the midpoint between the last rib and the iliac crest with participants standing and wearing only undergarments.

\section{Blood Glucose and Lipids}

Participants were asked to refrain from using laxatives containing glycerin for 48 hours and from consuming glycerin-containing products and other sweets for 24 hours prior to blood sampling. Blood was drawn in the fasting state; only water, black coffee, or unsweetened tea and medications other than antidiabetic medications were permitted during the 12 hours prior to sampling. Following the sampling, participants were allowed to resume their usual antidiabetic medication. Plasma glucose was assayed within 6 hours. Serum was assayed for high density lipoprotein cholesterol and triglycerides.

\section{Blood Pressure}

Blood pressure (at rest) was measured with the participant seated. Two readings were taken 5 minutes apart; if different by $>5 \mathrm{~mm} \mathrm{Hg}$, measurements were repeated until 2 concordant readings were obtained.

\section{Measurement of CCAIMT}

Far wall CCAIMT was evaluated according to the Mannheim intima-media thickness consensus [15]. Both common carotid arteries were examined by B-mode ultrasonography with participants in the supine position, using phased array 7.5 MHz transducers and ultrasound 
apparatus no older than 7 years. M'AthStd ${ }^{\circledR}$ software (Intelligence in Medical Technologies, Paris, France) automatically measured the CCAIMT; measurements were taken over a $10 \mathrm{~mm}$ length and averaged, and quality of acquisition was evaluated. Data were analyzed at a central laboratory at Intelligence in Medical Technologies, Paris, France.

\section{Definitions}

Diabetes was defined as a fasting plasma glucose level $\geq$ $7.0 \mathrm{mmol} / \mathrm{l}$ (126 mg/dL) [16] or self-reported diabetes. Metabolic syndrome was defined by NCEP ATP III criteria as the presence of 3 or more of the following: waist $>102$ $\mathrm{cm}$ in men, $>88 \mathrm{~cm}$ in women; triglycerides $\geq 1.70 \mathrm{mmol} /$ 1 (150 mg/dL); high density lipoprotein cholesterol (HDL-C) $<1.03 \mathrm{mmol} / \mathrm{l}(40 \mathrm{mg} / \mathrm{dL})$ in men, $<1.29 \mathrm{mmol} /$ l (50 mg/dL) in women; blood pressure $\geq 130 / 85 \mathrm{~mm} \mathrm{Hg}$; and fasting plasma glucose $\geq 6.11 \mathrm{mmol} / \mathrm{l}(110 \mathrm{mg} / \mathrm{dL})$ or self-reported diabetes [2].

\section{Statistical Analysis}

Statistical processing addressed the nonequal probability character of the sample and the structure of the design to generate data adjusted for the age and sex distribution of the population of each city. Means and prevalence along with their 95\% confidence intervals were estimated by survey analysis procedures (SAS Software, Release 9.1, Cary, North Carolina, USA), taking into account the multistage stratified sampling design via CLUSTER and STRATA statements.

\section{Results}

A total of 11,550 participants between the ages of 25 and 64 years were enrolled in CARMELA between September 2003 and August 2005. Data for 11,502 participants were evaluable for metabolic syndrome: Barquisimeto, $\mathrm{n}=$ 1,836; Bogotá, $\mathrm{n}=1,550$; Buenos Aires, $\mathrm{n}=1,476$; Lima, $\mathrm{n}=1,645$; Mexico City, $\mathrm{n}=1,720$; Quito, $\mathrm{n}=1,627$; and Santiago, $n=1,648$. Per the study design, age and sex distribution was relatively even for each city.

\section{Prevalence of the Metabolic Syndrome in the Overall CARMELA Population}

Metabolic syndrome was most prevalent in Mexico City (27\%) and Barquisimeto (26\%), followed by Santiago (21\%) and Bogota (20\%); lower prevalence was found in Lima $(18 \%)$, Buenos Aires (17\%), and Quito (14\%). Overall, metabolic syndrome was more prevalent in women than men (22\% vs $20 \%$, respectively), with the exception of Buenos Aires and Barquisimeto where more men than women had metabolic syndrome. As expected, the prevalence of metabolic syndrome increased with age. In all cities, women showed markedly greater increase in metabolic syndrome with increasing age than men; in the oldest age group, female prevalence (range 25\% to $49 \%$ ) was greater than male prevalence (range $13 \%$ to $38 \%$ ) in

Table I: Prevalence (\%) (95\% confidence interval) in the nondiabetic population* of the Metabolic Syndrome, according to NCEP ATP III.

\begin{tabular}{|c|c|c|c|c|c|}
\hline & \multicolumn{4}{|c|}{ Age group } & \multirow[b]{2}{*}{ Overall prevalence } \\
\hline & $25-34$ & $35-44$ & $45-54$ & $55-64$ & \\
\hline \multicolumn{6}{|c|}{ Barquisimeto } \\
\hline Men & 19.7 (I3.1-26.2) & $27.2(20.7-33.7)$ & $32.4(25.5-39.4)$ & 38.1 (30.7-45.5) & $23.0(19.1-27.0)$ \\
\hline Women & II.6 (7.2-16.0) & $23.9(19.2-28.6)$ & $37.7(32.3-43.1)$ & $47.8(41.8-53.8)$ & $22.7(20.0-25.3)$ \\
\hline \multicolumn{6}{|l|}{ Bogota } \\
\hline Men & $10.7(6.2-15.1)$ & I8.5 (|3.|-23.8) & $25.9(20.4-31.4)$ & 30.1 (22.9-37.3) & |4.7 (II.8-|7.5) \\
\hline Women & $8.3(4.6-11.9)$ & $16.8(10.8-22.7)$ & $36.2(30.2-42.3)$ & $48.6(41.8-55.5)$ & $18.2(15.5-20.9)$ \\
\hline \multicolumn{6}{|l|}{ Buenos Aires } \\
\hline Men & I I.8 (7.2- |6.4) & 21.8 (I5.7-27.9) & $26.6(20.3-32.9)$ & $33.0(26.0-40.0)$ & 17.3 (|4.8-19.8) \\
\hline Women & $3.3(0.8-5.9)$ & $7.5(3.6-11.4)$ & $16.9(10.4-23.5)$ & $24.6(\mid 7.8-31.4)$ & $9.7(7.1-12.3)$ \\
\hline \multicolumn{6}{|l|}{ Lima } \\
\hline Men & $10.0(5.9-14.2)$ & $15.8(9.0-22.5)$ & $19.8(14.1-25.4)$ & $25.1(18.2-32.1)$ & $13.2(10.6-15.8)$ \\
\hline Women & $6.4(3.2-9.7)$ & 18.7 (12.9-24.4) & $34.8(28.8-40.7)$ & $36.8(29.5-44.0)$ & $17.6(15.0-20.1)$ \\
\hline \multicolumn{6}{|l|}{ Mexico City } \\
\hline Men & $22.2(15.6-28.8)$ & $22.6(17.7-27.6)$ & $33.5(28.0-39.0)$ & $37.2(30.6-43.7)$ & $22.4(18.9-25.8)$ \\
\hline Women & 16.5 (II.9-2I.I) & $27.4(20.3-34.5)$ & $35.5(30.0-40.9)$ & $49.3(42.4-56.1)$ & $22.2(19.1-25.4)$ \\
\hline \multicolumn{6}{|l|}{ Quito } \\
\hline Men & $3.6(0.7-6.5)$ & $6.3(3.5-9.1)$ & $12.9(8.2-17.6)$ & 13.4 (8.6- |8.2) & $5.5(3.9-7.1)$ \\
\hline Women & $7.8(3.6-12.1)$ & I8.0 (I I.8-24.2) & $35.5(29.3-41.6)$ & 37.4 (3I.I-43.7) & $16.4(13.5-19.3)$ \\
\hline \multicolumn{6}{|l|}{ Santiago } \\
\hline Men & $9.9(5.8-14.0)$ & 17.5 (I2.0-23.0) & $27.0(20.8-33.1)$ & $31.5(25.5-37.4)$ & $15.3(12.8-17.9)$ \\
\hline Women & I I.6 (7.3-15.9) & $22.3(16.0-28.6)$ & $26.1(20.4-31.7)$ & $42.4(36.4-48.5)$ & $19.0(16.0-22.0)$ \\
\hline
\end{tabular}

*CARMELA participants excluding participants with fasting plasma glucose $\geq 7.0 \mathrm{mmol} / \mathrm{l}$ ( $126 \mathrm{mg} / \mathrm{dL})$ and/or self-reported diabetes. 
all cities except Buenos Aires (See Table 1 and Figure S1 in additional file 1). Of components of metabolic syndrome, the abdominal obesity was notably more prevalent in women than men, and the difference was accentuated in successively older age groups.

\section{Prevalence of Specific Components of the Metabolic Syndrome}

Table 2 reports the prevalence of each component of the metabolic syndrome within the population of all participants with metabolic syndrome (with or without a history of diabetes mellitus). Overall, $86 \%$ had high triglycerides, $86 \%$ had low HDL-C, and 60\% were hypertensive. Across cities, abdominal obesity was present in $81 \%$ to $93 \%$ of women, and in $46 \%$ to $73 \%$ of men with metabolic syndrome.

\section{Prevalence of the Metabolic Syndrome in Participants With Specific Components}

Prevalence of the metabolic syndrome in subsets of the overall population with specific components of the syndrome is reported in Table 3. Overall, approximately twothirds of men with abdominal obesity or glucose abnormalities, and approximately $60 \%$ to $70 \%$ of women with high triglycerides, hypertension, or glucose abnormalities had the full metabolic syndrome. In all cities except Mexico City, the prevalence of metabolic syndrome among participants with low HDL-C was fairly low. Prevalence of the syndrome among women with high triglycerides was notably higher than among men in all cities except Barquisimeto and Buenos Aires.

\section{Prevalence of Metabolic Syndrome Among Participants Without Diabetes}

Table 4 reports the prevalence of the number of components of the metabolic syndrome among CARMELA participants without a history of diabetes mellitus. In all cities, $>60 \%$ of the participants had at least 1 component of the metabolic syndrome. As in the overall CARMELA population, the prevalence of metabolic syndrome in the nondiabetic population was higher in women than men, except in Barquisimeto and Buenos Aires.

\section{Metabolic Syndrome and Carotid Atherosclerosis}

In both men and women overall, mean CCAIMT increased steeply with increasing numbers of metabolic syndrome components (Table 5 and Figure S2 in additional file 1). Similarly, the prevalence of carotid plaque also increased with increasing numbers of components and overall, was approximately 50\% more prevalent in

Table 2: Prevalence* and $95 \%$ confidence interval of specific components of the metabolic syndrome in population with metabolic syndrome

\begin{tabular}{|c|c|c|c|c|c|}
\hline & $\begin{array}{l}\text { Abdominal obesity } \\
>102 \mathrm{~cm} \text { in men or } \\
>88 \mathrm{~cm} \text { in women }\end{array}$ & $\begin{array}{c}\text { Triglycerides } \geq 1.70 \\
\mathrm{mmol} / \mathrm{l} \\
(150 \mathrm{mg} / \mathrm{dL})\end{array}$ & $\begin{array}{c}\text { HDL-C }<1.03 \mathrm{mmol} / \mathrm{l}(40 \\
\mathrm{mg} / \mathrm{dL}) \text { in } \mathrm{men} \text { or }<1.29 \\
\mathrm{mmol} / /(50 \mathrm{mg} / \mathrm{dL}) \text { in } \\
\text { women }\end{array}$ & $\begin{array}{l}\text { Blood pressure } \geq \\
\text { I } 30 / 85 \mathrm{~mm} \mathrm{Hg} \text { or } \\
\text { treatment }\end{array}$ & $\begin{array}{c}\text { Glucose abnor } \\
\text { malities }{ }^{\dagger}\end{array}$ \\
\hline Overall & $76.3(74.0-78.6)$ & $85.9(84.3-87.6)$ & $85.6(83.8-87.4)$ & $60.1(57.7-62.5)$ & $31.2(28.9-33.2)$ \\
\hline Men & $61.3(57.2-65.5)$ & $90.2(88.2-92.1)$ & $82.7(80.2-85.2)$ & $68.0(64.7-7 \mid .3)$ & $32.6(29.5-35.7)$ \\
\hline Women & $88.1(86.2-90.0)$ & $82.6(80.2-85.0)$ & $87.9(85.9-90.0)$ & $53.8(50.8-56.9)$ & $30.1(27.1-33.0)$ \\
\hline \multicolumn{6}{|l|}{ Barquisimeto } \\
\hline Men & $56.6(49.1-64.1)$ & $90.3(85.9-94.8)$ & $92.9(89.6-96.2)$ & $82.2(76.7-87.8)$ & 23.1 (I7.4-28.8) \\
\hline Women & $84.0(79.6-88.3)$ & $78.7(73.9-83.5)$ & $96.4(94.8-98.0)$ & $63.6(57.3-69.9)$ & $19.4(15.5-23.3)$ \\
\hline \multicolumn{6}{|l|}{ Bogota } \\
\hline Men & $45.8(35.6-56.1)$ & $92.1(87.5-96.8)$ & $92.9(89.1-96.8)$ & $57.6(48.8-66.3)$ & $40.6(32.1-49.2)$ \\
\hline Women & $86.0(81.5-90.5)$ & $83.3(78.3-88.2)$ & $93.7(90.2-97.2)$ & $49.8(42.2-57.4)$ & $28.6(22.2-34.9)$ \\
\hline \multicolumn{6}{|l|}{ Buenos Aires } \\
\hline Men & $73.1(65.6-80.5)$ & 77.5 (7I.I-84.0) & $67.7(60.2-75.2)$ & $93.2(89.5-96.8)$ & $31.8(24.0-39.7)$ \\
\hline Women & $88.9(82.9-94.9)$ & $65.4(56.7-74.0)$ & $79.9(72.4-87.3)$ & $77.3(68.3-86.4)$ & 31.1 (2I.3-40.9) \\
\hline \multicolumn{6}{|l|}{ Lima } \\
\hline Men & $55.3(46.5-64.2)$ & $87.3(81.8-92.7)$ & $93.4(89.0-97.7)$ & $70.5(62.9-78.0)$ & $30.7(22.0-39.5)$ \\
\hline Women & $80.8(75.2-86.3)$ & $82.6(76.9-88.4)$ & $97.9(95.8-100.0)$ & $51.7(44.3-59.1)$ & $24.0(18.6-29.3)$ \\
\hline \multicolumn{6}{|l|}{ Mexico City } \\
\hline Men & $72.7(65.9-79.5)$ & $93.0(89.7-96.3)$ & $78.0(73.7-83.9)$ & $58.3(52.8-63.7)$ & $30.4(24.5-36.2)$ \\
\hline Women & 93.1 (90.6-95.5) & $85.7(80.0-91.3)$ & $77.7(73.2-82.1)$ & $52.8(47.3-58.2)$ & $35.2(27.9-42.6)$ \\
\hline \multicolumn{6}{|l|}{ Quito } \\
\hline Men & $48.8(36.3-61.4)$ & $97.9(94.8-101.0)$ & $83.9(75.8-92.1)$ & $62.3(48.1-76.5)$ & $33.4(22.5-44.3)$ \\
\hline Women & 90.1 (85.5-94.7) & $83.3(79.0-87.7)$ & $92.0(88.9-95.1)$ & $37.0(28.7-45.2)$ & $32.6(26.1-39.1)$ \\
\hline \multicolumn{6}{|l|}{ Santiago } \\
\hline Men & $60.7(51.9-69.5)$ & $93.0(89.6-96.3)$ & 73.5 (66.4-80.7) & $76.6(69.1-84.0)$ & $31.4(24.9-37.9)$ \\
\hline Women & $90.6(86.7-94.4)$ & $82.9(77.6-88.2)$ & $86.6(81.9-91.2)$ & $57.1(50.6-63.6)$ & $31.1(24.1-38.1)$ \\
\hline
\end{tabular}

*Prevalence among participants with metabolic syndrome, with or without previously diagnosed diabetes mellitus.

tParticipants with fasting plasma glucose $>6.11 \mathrm{mmol} / \mathrm{l}(\mathrm{I} / 0 \mathrm{mg} / \mathrm{dL})$ or previous diagnosis of diabetes mellitus. 
Table 3: Prevalence (\%)(95\% confidence interval) of the metabolic syndrome among subsets of participants* with each of the 5 NCEP ATP III risk factor components of the syndrome

\begin{tabular}{|c|c|c|c|c|c|}
\hline & $\begin{array}{l}\text { Abdominal obesity } \\
>102 \mathrm{~cm} \text { in men or } \\
>88 \mathrm{~cm} \text { in women }\end{array}$ & $\begin{array}{c}\text { Triglycerides } \geq \mathrm{I} .70 \\
\mathrm{mmol} / \mathrm{l} \\
(\text { I } 50 \mathrm{mg} / \mathrm{dL})\end{array}$ & $\begin{array}{c}\text { HDL-C }<1.03 \mathrm{mmol} / \mathrm{l}(40 \\
\mathrm{mg} / \mathrm{dL}) \text { in } \mathrm{men} \text { or }<1.29 \\
\mathrm{mmol} / \mathrm{l}(50 \mathrm{mg} / \mathrm{dL}) \text { in } \\
\text { women }\end{array}$ & $\begin{array}{l}\text { Blood pressure } \geq \\
\text { I30/85 mm Hg or } \\
\text { treatment }\end{array}$ & $\begin{array}{c}\text { Glucose } \\
\text { abnormalities }\end{array}$ \\
\hline Overall & $53.3(51.0-55.5)$ & $45.7(43.9-47.5)$ & $34.6(33.0-36.2)$ & $52.5(50.3-54.7)$ & $71.6(68.3-74.8)$ \\
\hline Men & $64.0(60.3-67.7)$ & $36.2(34.0-38.4)$ & $35.5(33.0-38.0)$ & $47.5(44.7-50.2)$ & $70.5(66.4-74.7)$ \\
\hline Women & $48.7(45.9-51.6)$ & $59.0(56.2-61.9)$ & $34.0(32.0-36.0)$ & $58.7(55.6-61.8)$ & $72.5(67.7-77.2)$ \\
\hline \multicolumn{6}{|c|}{ Barquisimeto } \\
\hline Men & $75.7(66.9-84.5)$ & $50.3(44.5-56.1)$ & $34.5(29.1-39.9)$ & $60.2(53.7-66.7)$ & 82.1 (72.9-91.2) \\
\hline Women & $61.1(55.9-66.3)$ & $66.9(62.6-71.2)$ & $32.4(28.5-36.3)$ & $59.8(54.1-65.5)$ & 70.3 (59.4-8I.2) \\
\hline \multicolumn{6}{|l|}{ Bogota } \\
\hline Men & 77.1 (68.5-85.7) & $32.1(27.7-36.5)$ & $29.4(25.2-33.7)$ & $53.1(45.9-60.2)$ & $7 I . I(60.3-8 I .9)$ \\
\hline Women & $55.0(49.0-60.9)$ & $55.0(48.4-61.6)$ & $28.5(25.2-31.9)$ & $64.8(56.2-73.4)$ & $61.6(50.1-73.1)$ \\
\hline \multicolumn{6}{|c|}{ Buenos Aires } \\
\hline Men & $56.6(50.3-62.8)$ & $57.2(49.9-64.5)$ & $50.1(43.3-57.0)$ & $38.4(34.2-42.5)$ & $70.8(60.1-8 \mid .6)$ \\
\hline Women & $36.0(29.7-42.2)$ & $62.3(53.1-7 \mid .4)$ & $31.7(25.1-38.3)$ & $31.7(25.1-38.4)$ & $68.6(55.3-81.9)$ \\
\hline \multicolumn{6}{|l|}{ Lima } \\
\hline Men & $73.7(65.0-82.4)$ & 35.1 (29.4-40.7) & $22.9(18.9-26.8)$ & $46.4(39.1-53.6)$ & $74.5(63.2-85.8)$ \\
\hline Women & $50.9(44.3-57.5)$ & $61.5(55.2-67.8)$ & $24.3(21.1-27.5)$ & 64.1 (56.7-7I.5) & $76.6(65.7-87.4)$ \\
\hline \multicolumn{6}{|l|}{ Mexico City } \\
\hline Men & $59.6(52.4-66.8)$ & $38.3(33.6-43.0)$ & 58.8 (5।.7-65.9) & $61.8(55.2-68.5)$ & 7I.I (64.7-77.4) \\
\hline Women & $46.7(40.2-53.2)$ & $59.3(53.5-65.1)$ & $53.0(47.1-58.9)$ & $67.7(60.3-75.1)$ & 79.5 (7I.6-87.5) \\
\hline \multicolumn{6}{|l|}{ Quito } \\
\hline Men & $66.2(52.3-80.1)$ & | 4.5 (| I.|-|7.9) & $22.6(16.9-28.2)$ & $34.1(25.7-42.5)$ & 44.5 (31.8-57.2) \\
\hline Women & $46.2(40.9-5 \mid .5)$ & $51.3(42.9-59.7)$ & $38.6(32.8-44.4)$ & $62.2(53.7-70.7)$ & 71.9 (62.I-8I.7) \\
\hline \multicolumn{6}{|l|}{ Santiago } \\
\hline Men & 6I.I (52.6-69.7) & $36.4(3|.5-4| .3)$ & 44.8 (38.4-5I.I) & $39.5(34.1-44.8)$ & 68.1 (58.8-77.3) \\
\hline Women & $47.8(42.6-52.9)$ & $61.9(56.1-67.8)$ & 43.3 (37.8-48.9) & $57.6(5 \mid .7-63.5)$ & $74.9(65.4-84.5)$ \\
\hline
\end{tabular}

*All participants, with or without diabetes mellitus, were grouped by presence of specific components, and prevalence of metabolic syndrome within each group is reported here.

†All participants with fasting plasma glucose $>6.11 \mathrm{mmol} / \mathrm{l}(110 \mathrm{mg} / \mathrm{dL})$ or previous diagnosis of diabetes mellitus.

both men and women with metabolic syndrome than those without. In all cities, mean CCAIMT and prevalence of plaque were higher in participants with metabolic syndrome than those without.

\section{Discussion}

The CARMELA study reports overall prevalence of $21 \%$ of metabolic syndrome by NCEP ATP III criteria in the 7 Latin American cities studied. Profiles of the metabolic syndrome according to sex varied among cities. Among the overall population and the nondiabetic population, the highest prevalence of metabolic syndrome was found in Barquisimeto and Mexico City. Women of Bogota, Lima, Quito, and Santiago had greater prevalence of metabolic syndrome than their male counterparts, while the opposite was true in Buenos Aires. Not surprisingly, prevalence of metabolic syndrome increased with age, strikingly so in women. Participants with metabolic syndrome had higher mean CCAIMT and prevalence of carotid plaque than those without the syndrome.

The prevalence of metabolic syndrome found in CARMELA approximates prevalence estimates (23\% to $27 \%$ ) in the United States [6,13]. Direct comparison with other Latin America studies using NCEP ATP III criteria show CARMELA prevalence to be consistent with prevalence in Mexico $[17,18]$. Also by NCEP ATP III criteria, $31 \%$ of a population of Zulia State, Venezuela [19], and 12\% and $26 \%$ of men and women of Lima [18], respectively, were found to have metabolic syndrome. CARMELA reports lower prevalence in Barquisimeto than elsewhere in Venezuela, and prevalence that is less disparate between the sexes of Lima; however, CARMELA targeted a much broader population base than in the aforementioned study in Lima. In the Estudio Peruano de Prevalencia de Enfermedades Cardiovasculares, or Peruvian Study of the Prevalence of Cardiovascular Risk Factors (PREVENCION) study in another urban region of Peru, $14 \%$ and $23 \%$ of men and women, respectively, were found to have the syndrome [20].

Whereas it has been suggested that the burden of metabolic syndrome is growing in younger populations, especially in developing regions [21], metabolic syndrome increases with age as CARMELA results confirm. Elevated body weight, waist circumference, and low HDL-C levels 
Table 4: Prevalence (\%) (95\% confidence interval) in the nondiabetic population* of I to 5 of the NCEP ATP III risk factor components of the metabolic syndrome and diagnosis of metabolic syndrome

\begin{tabular}{|c|c|c|c|c|c|c|}
\hline & \multicolumn{6}{|c|}{ Number of Components } \\
\hline & 0 & $\mathbf{I}$ & 2 & 3 & 4 & 5 \\
\hline Overall & $23.4(22.3-24.5)$ & $32.8(31.7-34.0)$ & $26.5(25.4-27.6)$ & $13.0(12.2-13.8)$ & $4.0(3.6-4.4)$ & $0.3(0.2-0.4)$ \\
\hline Men & $24.6(23.1-26.2)$ & $30.8(29.1-32.4)$ & $28.5(26.9-30.0)$ & $12.2(11.1-13.4)$ & $3.6(3.0-4.1)$ & $0.3(0.1-0.5)$ \\
\hline Women & $22.3(20.8-23.8)$ & $34.7(33.0-36.3)$ & $24.8(23.3-26.2)$ & $13.7(\mid 2.5-14.8)$ & $4.3(3.8-4.9)$ & $0.3(0.1-0.4)$ \\
\hline \multicolumn{7}{|l|}{ Barquisimeto } \\
\hline Men & I4.I (|I.2-16.7) & $32.6(28.3-37.0)$ & $30.3(26.5-34.1)$ & $15.8(12.8-18.8)$ & $6.7(4.7-8.8)$ & $0.5(0.0-1.0)$ \\
\hline Women & $13.4(10.9-16.0)$ & $37.5(33.8-4 \mid .2)$ & $26.4(23.4-29.5)$ & $16.3(14.0-18.5)$ & $6.2(4.7-7.8)$ & $0.2(0.0-0.3)$ \\
\hline \multicolumn{7}{|l|}{ Bogota } \\
\hline Men & $21.6(18.1-25.0)$ & $30.7(26.6-34.9)$ & $33.0(29.4-36.6)$ & II.4 (8.6-I4.2) & $3.0(1.8-4.1)$ & $0.3(0.0-0.7)$ \\
\hline Women & $17.6(14.3-20.9)$ & $35.4(31.9-38.9)$ & $28.8(25.5-32.1)$ & $14.0(\mid 1.2-16.8)$ & $4.0(2.9-5.2)$ & $0.2(0.0-0.4)$ \\
\hline \multicolumn{7}{|l|}{ Buenos Aires } \\
\hline Men & $28.5(25 .|-3| .9)$ & $30.2(27.3-33.1)$ & $24.0(20.4-27.5)$ & $12.7(10.5-15.0)$ & $4.4(2.9-5.9)$ & $0.2(0.0-0.5)$ \\
\hline Women & $37.7(33.8-41.5)$ & $36.7(32.8-40.6)$ & $15.9(13.0-18.8)$ & $7.5(5.4-9.6)$ & $2.1(0.8-3.3)$ & $0.1(0.0-0.4)$ \\
\hline \multicolumn{7}{|l|}{ Lima } \\
\hline Men & $21.5(18.0-25.0)$ & $35.8(32.0-39.7)$ & $29.5(26.0-33.0)$ & 9.7 (7.5- I I.8) & $3.2(1.9-4.5)$ & $0.3(0.0-0.6)$ \\
\hline Women & I2.I (9.5- I4.7) & $44.2(40.4-48.1)$ & $26.1(22.7-29.5)$ & $13.2(10.9-15.3)$ & $4.2(3.0-5.5)$ & $0.2(0.0-0.5)$ \\
\hline \multicolumn{7}{|l|}{ Mexico City } \\
\hline Men & $23.7(20.5-27.0)$ & $26.0(23.4-28.5)$ & $27.9(24.7-3 \mid .1)$ & $17.3(|4|-20.5)$. & $4.6(3.2-6.0)$ & $0.5(0.0-1.0)$ \\
\hline Women & $24.3(20.7-27.8)$ & $27.5(24.1-31.0)$ & $26.0(22.9-29.0)$ & $16.7(14.0-19.4)$ & $5.0(3.7-6.3)$ & $0.5(0.0-1.0)$ \\
\hline \multicolumn{7}{|l|}{ Quito } \\
\hline Men & $39.2(34.8-43.5)$ & $32.5(28.9-36.0)$ & $22.8(19.8-25.9)$ & $4.3(2.9-5.8)$ & I.I (0.4-I.8) & $0.1(0.0-0.2)$ \\
\hline Women & $30.5(26.9-34.1)$ & $30.9(27.2-34.5)$ & $22.2(18.8-25.7)$ & $13.4(10.8-16.1)$ & $2.7(1.7-3.6)$ & $0.3(0.0-0.6)$ \\
\hline \multicolumn{7}{|l|}{ Santiago } \\
\hline Men & $28.6(24.5-32.6)$ & $29.8(25.6-33.9)$ & $26.3(22.7-29.9)$ & $11.7(9.5-14.1)$ & $3.3(2.0-4.5)$ & $0.3(0.0-0.7)$ \\
\hline Women & $28.6(24.8-32.3)$ & $30.5(26.9-34.2)$ & $21.9(19.1-24.8)$ & $13.3(10.8-15.8)$ & $5.5(3.8-7.1)$ & $0.2(0.0-0.5)$ \\
\hline
\end{tabular}

*CARMELA participants excluding participants with fasting plasma glucose $\geq 7.0 \mathrm{mmol} / \mathrm{l}(126 \mathrm{mg} / \mathrm{dL})$ and/or self-reported diabetes.

have been found to be more common contributors to metabolic syndrome in women, while blood pressure and apolipoprotein B have been found to be more common contributors in men [22]. Obesity in women is increasing faster than in men [23] and the metabolic syndrome increases in a parallel manner. In many women, menopause is accompanied by the emergence of features of the metabolic syndrome and increased cardiovascular risk, whether as a direct result of ovarian failure or indirectly related to central adipose redistribution $[23,24]$. With this constellation of factors, it has even been suggested that the metabolic syndrome should be defined by different criteria in men and women [22]. CARMELA results illustrate the amplified increase in metabolic syndrome in women as opposed to men as women reach menopausal age. A study of post-menopausal Ecuadorian women [25] revealed an overall prevalence of metabolic syndrome of $42 \%$, similar to that found in CARMELA, with prevalence of hypertension, abdominal obesity, and low HDL-C similar to that in women in the older 2 CARMELA age groups. In a broader study of postmenopausal Latin American women, rates of metabolic syndrome in women of Bue-

Table 5: Mean CCAIMT ( $\mathrm{mm})$, prevalence $(\%)$ and $95 \%$ confidence intervals, of carotid plaque according to the number of components of the metabolic syndrome by NCEP ATP III criteria in the CARMELA participants*

\begin{tabular}{|c|c|c|c|c|c|c|c|c|}
\hline $\begin{array}{l}\text { Number of } \\
\text { components }\end{array}$ & 0 & $\mathbf{I}$ & 2 & 3 & 4 & 5 & $\begin{array}{c}\text { No } \\
\text { metabolic } \\
\text { syndrome }\end{array}$ & $\begin{array}{l}\text { Metabolic } \\
\text { syndrome }\end{array}$ \\
\hline \multicolumn{9}{|c|}{ Mean CCAIMT } \\
\hline Men & $\begin{array}{c}0.623 \\
(0.616-0.629)\end{array}$ & $\begin{array}{c}0.644 \\
(0.637-0.650)\end{array}$ & $\begin{array}{c}0.665 \\
(0.658-0.672)\end{array}$ & $\begin{array}{c}0.688 \\
(0.679-0.697)\end{array}$ & $\begin{array}{c}0.707 \\
(0.694-0.720)\end{array}$ & $\begin{array}{c}0.731 \\
(0.701-0.76 I)\end{array}$ & $\begin{array}{c}0.645 \\
(0.640-0.650)\end{array}$ & $\begin{array}{c}0.695 \\
(0.687-0.702)\end{array}$ \\
\hline Women & $\begin{array}{c}0.624 \\
(0.617-0.632)\end{array}$ & $\begin{array}{c}0.624 \\
(0.618-0.631)\end{array}$ & $\begin{array}{c}0.645 \\
(0.639-0.652)\end{array}$ & $\begin{array}{c}0.668 \\
(0.662-0.675)\end{array}$ & $\begin{array}{c}0.709 \\
(0.696-0.721)\end{array}$ & $\begin{array}{c}0.704 \\
(0.685-0.723)\end{array}$ & $\begin{array}{c}0.631 \\
(0.626-0.636)\end{array}$ & $\begin{array}{c}0.682 \\
(0.676-0.688)\end{array}$ \\
\hline \multicolumn{9}{|c|}{ Prevalence of carotid plaque } \\
\hline Men & $4.0(2.7-5.2)$ & $7.2(5.7-8.6)$ & $7.8(6.2-9.4)$ & $9.3(6.9-11.7)$ & $9.7(5.9-13.4)$ & $11.4(3.4-19.4)$ & $6.4(5.5-7.4)$ & $9.5(7.4-11.6)$ \\
\hline Women & $4.9(3.5-6.2)$ & $7.4(5.9-8.8)$ & $7.8(6.3-9.4)$ & $10.9(8.5-13.3)$ & $11.7(8.1-15.4)$ & $12.5(6.2-18.8)$ & $6.8(5.9-7.7)$ & $11.2(9.3-13.2)$ \\
\hline
\end{tabular}

*CARMELA survey participants, including those with previous history of diabetes mellitus.

CCAIMT = carotid artery intima-media thickness 
nos Aires were higher and those of Bogota, Lima, and Santiago, similar to those of women in the oldest 2 CARMELA age groups [26]. Although in all CARMELA cities, older women showed strikingly higher abdominal obesity rates than men, high rates of abdominal obesity were found in women of all age groups.

In designing targeted programs for detection and treatment of metabolic syndrome, CARMELA provides crucial data on the sensitivity and predictive value of each component. On the one hand, of the general population of men in CARMELA cities (except for Quito where lower prevalence of metabolic syndrome in men is noted), approximately $70 \%$ of those with glucose abnormalities, approximately two-thirds of those with abdominal obesity, and half with hypertension, will have the full syndrome. Of the general population of women in CARMELA cities, nearly three-quarters of those with glucose abnormalities, and approximately $50 \%$ to $60 \%$ with abdominal obesity, high triglycerides, or hypertension, will have the full metabolic syndrome (Table 2). On the other hand, once metabolic syndrome is diagnosed, the shape of the syndrome is characterized by predominance of hypertension, low HDL-C and high triglycerides in men, and predominance of abdominal obesity, high triglycerides, and a remarkable predominance of low HDL-C in women (Table 3). Thus, hypertension, low HDL-C, and high triglycerides in men and low HDL-C in particular, along with high triglycerides and abdominal obesity in women, are highly specific indicators of the syndrome. CARMELA provides data which confirms the likelihood of finding other specific components, once metabolic syndrome is diagnosed. Although the metabolic syndrome predicts diabetes along with cardiovascular risk, glucose abnormalities in and of themselves are not particularly specific to the full syndrome. This notion is confirmed by the similar prevalence of metabolic syndrome in CARMELA populations that both include and exclude diabetes. Since the metabolic syndrome is epitomized by the development of diabetes, its presence in the nondiabetic population is of particular importance.

To our knowledge, this is the first study that provides evidence of a relationship between the occurrence of the metabolic syndrome and the presence of carotid atherosclerosis in the Latin American population. A large study in Italy reported increased incidence of carotid plaques and stenosis over 5 years of follow-up in participants with metabolic syndrome [9]. Metabolic syndrome has also been associated with incident stroke in both black and white populations in the United States [6] and with higher carotid intima-media thickness and prevalence of plaques in elderly French individuals [27]. Metabolic syndrome has also been associated with tissue characteristics of the intima-media complex in the carotid artery [28], and the increasing number of components of the metabolic syndrome have also been related to higher carotid artery stiffness [29]. In other studies, the association between metabolic syndrome and carotid atherosclerosis has been reported to be stronger in women than men [30], however, in the CARMELA study it seems to be quite similar for men and women. Carotid intima-media thickening as an indicator of atherosclerosis in other vascular beds [31] is a strong predictor of future cardiovascular events [32]. The relationship between metabolic syndrome and carotid atherosclerosis noted in CARMELA enhances previous findings of metabolic syndrome as a cardiovascular disease predictor $[3,7,9]$.

The value of CARMELA lies in its carefully constructed sampling of populations by age and sex to elucidate prevalence of metabolic syndrome components. Urban vs rural and ethnic differences in prevalence of metabolic syndrome have been reported in a variety of Latin American settings [33] and should be investigated further. Genetic predispositions to the metabolic syndrome [34], along with cultural and nutritional variations, also need investigation given Latin America's unique conglomeration of indigenous and immigrant populations. The obesity epidemic clearly affects the prevalence of metabolic syndrome among women but also extends to the young; CARMELA's lowest age range (25 to 34 years) may not have fully encompassed populations at risk, nor did CARMELA include increasingly older populations, which until now have borne the brunt of chronic disease. Rigorous studies like CARMELA should aid in designing targeted solutions to increasing rates of metabolic syndrome and its consequences.

In the Shape of the Nations Survey, 39\% of participants worldwide who visited primary care physicians were overweight or obese, but only $58 \%$ of primary care physicians recognized that abdominal obesity was a significant risk factor for cardiovascular disease, and 45\% reported that they never measured waist circumference [35]. As alarming as these statistics are, CARMELA findings reinforce the notion that metabolic syndrome is prevalent in urban Latin America and should be sought in the presence of even 1 component of the syndrome. Likewise, carotid atherosclerosis in Latin American individuals should spur healthcare providers to seek evidence of metabolic syndrome components and effect appropriate interventions. Guidelines for treatment of specific components in the context of the full metabolic syndrome are being developed [2] and should be promoted by healthcare educators and providers. The chronic disease burden consequent to metabolic syndrome will be extensive and expensive in Latin America if studies like CARMELA are ignored. 


\section{Conclusion}

CARMELA reports high prevalence of metabolic syndrome in 7 Latin American cities. Although rates varied between cities, there was a striking increase in the prevalence of metabolic syndrome with age, especially in women. CARMELA provides evidence for the association of metabolic syndrome with evidence of carotid atherosclerosis--namely increasing mean CCAIMT and plaque with increasing numbers of components of the syndrome, and overall higher mean CCAIMT and plaque in participants with the syndrome compared with those without. It is incumbent on government agencies and the medical community to address current prevalence of metabolic syndrome in order to prevent the dire consequences of increased burden of disease.

\section{Competing interests}

$\mathrm{RV}$ is a permanent employee of Pfizer Inc, makers of a cholesterol-regulating drug, and has shares in the company. HS was an employee of Pfizer, Inc. during the conduct of the study (now retired). All other authors declare no competing interests.

\section{Authors' contributions}

JE participated in the design and coordination of the study and drafted the manuscript. HSc conceived of the study, and participated in its design and coordination and helped to draft the manuscript. BC conceived of the study, and participated in its design and coordination and helped to draft the manuscript. HSi conceived of the study, and participated in its design and coordination and helped to draft the manuscript. CPB participated in the design and coordination of the study and helped to draft the manuscript. RV participated in the design and coordination of the study and helped to draft the manuscript. MT carried out the lab standardization. RH conceived of the study, and participated in its design and coordination and helped to draft the manuscript. EW conceived of the study, and participated in its design and coordination and helped to draft the manuscript.

All authors read and approved the final manuscript.

\section{Additional material}

\section{Additional file 1}

Figure S1. Prevalence of metabolic syndrome in each city, by age and sex. Figure S2. Mean CCAIMT and prevalence of plaque (95\% Confidence Intervals), by city. Additional file 1 includes a couple of figures that help to understand data.

Click here for file

[http://www.biomedcentral.com/content/supplementary/14752840-8-52-S1.DOC]

\section{Acknowledgements}

The authors would like to thank participating institutions, coordinators, and investigators: Asociación Cardiovascular Centro Occidental (Barquisimeto) - Lic. Elizabeth Infante, Luis Rocha; Pontificia Universidad Javeriana de Bogota (Bogota) - Álvaro Ruíz Morales, Esperanza Peña, Felipe Uriza; Centro de Educación Medica e Investigaciones Clinicas "Norberto Quirno"(Buenos Aires) - Carlos Boissonnet, Juan Fuselli, Víctor Torres; Universidad Cayetano Heredia (Lima) - Raúl Gamboa-Aboado, Carlos Kiyán, Mario Vargas; Instituto Mexicano del Seguro Social (Mexico City) Jorge Escobedo-de la Peña, Luisa Virginia Buitrón, Jesús Ramírez-Martínez; Hospital Metropolitano de Quito (Quito) - Francisco Benítez, María Velasco, Luis Falcóni; Pontificia Universidad Católica de Santiago de Chile (Santiago) - Ximena Berrios-Carrasola, Beatriz Guzmán, Mónica Acevedo.

\section{References}

I. Cornier MA, Dabelea D, Hernandez TL, Lindstrom RC, Steig AJ, Stob NR, Van Pelt RE, Wang H, Eckel RH: The metabolic syndrome. Endocrine Rev 2008, 29:777-822.

2. National Cholesterol Education Program (NCEP) Expert Panel on Detection, Evaluation, and Treatment of High Blood Cholesterol in Adults (Adult Treatment Panel III): Third Report of the National Cholesterol Education Program (NCEP) Expert Panel on Detection, Evaluation, and Treatment of High Blood Cholesterol in Adults (Adult Treatment Panel III) final report. Circulation 2002, I06:3|43-342I.

3. Eberly LE, Prineas R, Cohen JD, Vazquez G, Zhi X, Neaton JD, Kuller LH, for the Multiple Risk Factor Intervention Trial Research Group: Metabolic syndrome. Risk factor distribution and I8-year mortality in the Multiple Risk Factor Intervention Trial. Diabetes Care 2006, 29:123-130.

4. Malik S, Wong ND, Franklin SS, Kamath TV, L'Italien GJ, Pio JR, Williams GR: Impact of the metabolic syndrome on mortality from coronary heart disease, cardiovascular disease, and all causes in United States adults. Circulation 2004, I I 0: I 245- I 250.

5. Nilsson PM, Engstrom G, Hedblad B: The metabolic syndrome and incidence of cardiovascular disease in non-diabetic subjects--a population-based study comparing three different definitions. Diabet Med 2007, 24:464-472.

6. McNeill AM, Rosamond WD, Girman C], Golden SH, Schmidt MI, East HE, Ballantyne CM, Heiss G: The metabolic syndrome and I I-year risk of incident cardiovascular disease in the Atherosclerosis Risk in Communities Study. Diabetes Care 2005, 28:385-390.

7. Ford ES: Risks for all-cause mortality, cardiovascular disease, and diabetes associated with the metabolic syndrome: a summary of the evidence. Diabetes Care 2005, 28: 1769-1778.

8. Empana JP, Duciemetiere P, Balkau B, Jouven X: Contribution of the metabolic syndrome to sudden death risk in asymptomatic men: the Paris Prospective Study I. Eur Heart J 2007, 28: I|49-III54.

9. Bonora E, Kiechl S, Willeit J, Oberhollenzer F, Egger G, Bonadonna RC, Muggeo M: Carotid atherosclerosis and coronary heart disease in the metabolic syndrome. Prospective data from the Bruneck Study. Diabetes Care 2003, 26: 125I-I 257.

10. Desroches S, Lamarche $B$ : The evolving definitions and increasing prevalence of the metabolic syndrome. Appl Physiol Nutr Metab 2007, 32:23-32.

1I. Kolovou GD, Anagnostopoulou KK, Salpea KD, Mikhailidis DP: The prevalence of metabolic syndrome in various populations. Am J Med Sci 2007, 333:362-371.

12. Procopiou M, Philippe J: The metabolic syndrome and type 2 diabetes: epidemiological figures and country specificities. Cerebrovasc Dis 2005, 20(Suppl I):2-8.

13. Ford ES, Giles WH, Mokdad AH: Increasing prevalence of the metabolic syndrome among U.S. adults. Diabetes Care 2004, 27:2444-2449.

14. Schargrodsky H, Hernandez-Hernandez R, Champagne BM, Silva $H$, Vinueza R, Silva-Ayçaguer LC, Touboul PJ, Boissonnet CP, Escobedo J, Pellegrini F, Macchia A, Wilson E, for the CARMELA Study Investigators: CARMELA: assessment of cardiovascular risk in seven Latin American cities. Am J Med 2008, I 21 :58-65. 
15. Touboul PJ, Hennerici MG, Meairs S, Adams H, Amarenco P, Bornstein N, Csiba L, Desvarieux M, Ebrahim S, Fatar M, Hernandez Hernandez R, Jaff M, Kownator S, Prati P, Rundek T, Sitzer M, Schminke U, Tardif JC, Taylor A, Vicaut E, Woo KS, Zannad F, Zureik M: Mannheim carotid intima-media thickness consensus (20042006). An update on behalf of the Advisory Board of the 3rd and 4th Watching the Risk Symposium, I3th and I5th European Stroke Conferences, Mannheim, Germany, 2004, and Brussels, Belgium, 2006. Cerebrovasc Dis 2007, 23:75-80.

16. Expert Committee on the Diagnosis and Classification of Diabetes Mellitus: Report of the expert committee on the diagnosis and classification of diabetes mellitus. Diabetes Care 2003, 26(Suppl I):S5-S20.

17. Aguilar-Salinas CA, Rojas R, Gomez-Perez FJ, Valles V, Rios-Torres JM, Franco A, Olaiz G, Rull JA, Sepulveda J: High prevalence of metabolic syndrome in Mexico. Arch Med Res 2004, 35:76-8I.

18. Lorenzo C, Serrano-Rios M, Martinez-Larrad MT, González-Sánchez JL, Seclén S, Villena A, González-Villalpando C, Williams K, Haffner SM: Geographic variations of the International Diabetes Federation and the National Cholesterol Education ProgramAdult Treatment Panel III definitions of the metabolic syndrome in nondiabetic subjects. Diabetes Care 2006, 29:685-69l.

19. Florez H, Silva E, Fernandez V, Ryder E, Sulbaran T, Campos G, Calmon G, Clavel E, Castillo-Florez S, Goldberg R: Prevalence and risk factors associated with the metabolic syndrome and dyslipidemia in White, Black, Amerindian and Mixed Hispanics in Zulia State, Venezuela. Diabetes Res Clin Pract 2005, 69:63-77.

20. Medina-Lezama J, Zea-Diaz H, Morey-Vargas OL, Bolaños-Salazar JF, Muñoz-Atahualpa E, Postigo-MacDowall M, Corrales-Medina F, Valdivia-Ascuña Z, Cuba-Bustinza C, Paredes-Díaz S, Villalobos-Tapia P, Chirinos-Pacheco J, Goldberg RB, Chirinos JA: Prevalence of the metabolic syndrome in Peruvian Andean hispanics: The PREVENCION study. Diabetes Res Clin Pract 2007, 78:270-28I.

21. Rodgers A, Ezzati M, Vander Hoorn S, Lopez AD, Lin RB, Murray C): Comparative Risk Assessment Collaborating Group. Distribution of major health risks: findings from the Global Burden of Disease study. PLoS Med 2004, I:e27.

22. Dallongeville J, Cottel D, Arveiler D, Tauber JP, Bingham A, Wagner $A$, Fauvel ], Ferrières ], Ducimetière $P$, Amouyel $P$ : The association of metabolic disorders with the metabolic syndrome is different in men and women. Ann Nutr Metab 2004, 48:43-50.

23. Mitrakou A: Women's health and the metabolic syndrome. Ann N Y Acad Sci 2006, 1092:33-48.

24. Pramparo P, Schargrodsky H, Boissonnet C, Champagne BM, Silva H, Acevedo $M$, Wilson E: Cardiovascular risk factors for heart disease and stroke in women by age and time since menopause, in seven Latin American cities: The CARMELA Study. CVD Prev Control 2008, 3:18|-|89.

25. Hidalgo LA, Chedraui PA, Morocho N, Alvarado M, Chavez D, Huc $A$ : The metabolic syndrome among postmenopausal women in Ecuador. Gynecol Endocrinol 2006, 22:447-454.

26. Royer M, Castelo-Branco C, Blumel JE, Chedraui PA, Danckers L, Bencosme A, Navarro D, Vallejo S, Espinoza MT, Gómez G, Izaguirre $H$, Ayala F, Martino M, Ojeda E, Onatra W, Saavedra J, Tserotas K, Pozzo E, Manriquez V, Prada M, Grandia E, Zuniga C, Lange D, Sayegh F, Collaborative Group for Research of the Climacteric in Latin America: The US National Cholesterol Education Programme Adult Treatment Panel III (NCEP ATP III): prevalence of the metabolic syndrome in postmenopausal Latin American women. Climacteric 2007, 10:164-170.

27. Empana JP, Zureik M, Gariepy J, Courbon D, Dartigues JF, Ritchie K, Tzourio C, Alperovitch A, Ducimetiere P: The metabolic syndrome and the carotid artery structure in noninstitutionalized elderly subjects: the three-city study. Stroke 2007, 38:893-899.

28. Katakami N, Kaneto H, Matsuhisa M, Umayahara Y, Kosugi K, Yamasaki Y: Clustering of several cardiovascular risk factors affects tissue characteristics of the carotid artery. Atherosclerosis 2008 , 1 98:208-2 I3.

29. Martens FM, van der Graaf Y, Dijk JM, Olijhoek JK, Visseren FL: Carotid arterial stiffness is marginally higher in the metabolic syndrome and markedly higher in type 2 diabetes mellitus in patients with manifestations of arterial disease. Atherosclerosis 2008, 197:646-653.

30. Iglseder B, Cip P, Malaimare L, Ladurner G, Paulweber B: The metabolic syndrome is a stronger risk factor for early carotid atherosclerosis in women than in men. Stroke 2005, 36: $1212-1217$.

31. Bots ML, Baldassarre D, Simon A, de Groot E, O'Leary DH, Riley W, Kastelein J], Grobbee DE: Carotid intima-media thickness and coronary atherosclerosis: weak or strong relations? Eur Heart J 2007, 28:398-406.

32. Lorenz MW, Markus HS, Bots ML, Rosvall M, Sitzer M: Prediction of clinical cardiovascular events with carotid intima-media thickness: a systematic review and meta-analysis. Circulation 2007, I I 5:459-467.

33. Gregory CO, Dai J, Ramirez-Zea M, Stein AD: Occupation is more important than rural or urban residence in explaining the prevalence of metabolic and cardiovascular disease risk in Guatemalan adults. J Nutr 2007, 137:1314-1319.

34. Albala C, Villarroel A, Santos JL, Angel B, Lera L, Liberman C, Sanchez $\mathrm{H}$, Pérez-Bravo F: FABP2 Ala54Thr polymorphism and diabetes in Chilean elders. Diabetes Res Clin Pract 2007, 77:245-250.

35. Smith SC Jr, Haslam D: Abdominal obesity, waist circumference and cardio-metabolic risk: awareness among primary care physicians, the general population and patients at risk--the Shape of the Nations survey. Curr Med Res Opin 2007, 23:29-47.
Publish with Bio Med Central and every scientist can read your work free of charge

"BioMed Central will be the most significant development for disseminating the results of biomedical research in our lifetime. "

Sir Paul Nurse, Cancer Research UK

Your research papers will be:

- available free of charge to the entire biomedical community

- peer reviewed and published immediately upon acceptance

- cited in PubMed and archived on PubMed Central

- yours - you keep the copyright

Submit your manuscript here:

http://www.biomedcentral.com/info/publishing_adv.asp
BioMedcentral 